\title{
The perfect storm. An analysis of the processes that increase lethal violence in Mexico after 2006
}

\author{
Iván Flores Martínez ${ }^{1,2}$ (D) Matthew Phillips ${ }^{1,2}$
}

Accepted: 4 March 2021 /Published online: 27 April 2021

(C) The Author(s), under exclusive licence to Springer Science+Business Media, LLC, part of Springer Nature 2021

\begin{abstract}
Research on 'the War on Drugs' in Mexico finds that military interventions increase lethal violence in the country. However, these studies fail to account for other processes that may be driving the behavior of lethal violence in the Mexican municipalities. We find confirmation that these rival processes influence the relative impact that military interventions have on lethal violence. In particular, we find that seasonality in violence, competition for scarce resources and PAN's governance in the municipalities are associated with higher levels of lethal violence, as measured by the young male homicide rate. We argue that the literature may have overestimated the effect that military interventions have in lethal violence in municipalities and that other drivers of violence should be taken into account to accurately measure the impact that military interventions have on lethal violence.
\end{abstract}

Keywords Drug related violence · Organized Crime in Mexico · DTO's competition · Seasonality in Violence · Military Interventions

\section{Introduction}

Research on 'the War on Drugs' in Mexico finds that military interventions increase lethal violence in the country (Escalante Gonzalbo, 2011a; Merino 2011; Molzahn et al. 2012; Espinosa \& Rubin, 2015; Atuesta 2018). However, these studies fail to account for other processes that may be driving the behavior of lethal violence in the Mexican

Iván Flores Martínez

ifloresm@uncc.edu

Matthew Phillips

mdphill1@uncc.edu

1 Public Policy Program, UNCC, Charlotte, NC, USA

2 Department of Criminal Justice and Criminology, UNCC, Charlotte, NC, USA 
municipalities. For example, research suggests that drug related violence has seasonal components associated to drug cartels' competition for opium cultivation sites (Phillips, 2016). This seasonality in violence might partially account for the influence that military interventions have on lethal violence. ${ }^{1}$ In addition, research suggest that the presence of multiple DTOs in a municipality increases competition between DTOs for drug trafficking routes, strategic sites and resources (CITpax and Observatorio Internacional 2012; Dube and Vargas 2013; Calderón et al. 2015; Wagner, 2016). The literature also associates rule by the Party of National Action (Partido Acción Nacional in Spanish, or PAN) and party alternation at the state and municipal levels with increased lethal violence (Astorga 2005a Astorga and Shirk 2010; Dube and Vargas 2013; Ríos 2015; Trejo \& Ley, 2018). However, none of the studies on military interventions and violence account for these factors. It is the purpose of this paper to introduce a more refined model that is suggested by the literature and that includes measures of rival processes (chiefly, DTO competition, scarce resources, and PAN governance) that affect lethal violence in Mexican municipalities, alongside military interventions.

We review the literature on 'The War on Drugs' in Mexico to identify a model that we believe closely measures the effect that military interventions have on lethal violence. We build on the baseline model proposed by Atuesta (2018) for three reasons. First, it uses a mixed effects specification that controls for state characteristics that could influence the levels of lethal violence in a municipality after a military intervention. Second, the model identifies different types of governmental intervention and their relative impacts, which is important to derive policy implications. Third, journalists, security analysts, and public opinion leaders consistently use the general results from this study to argue against the militarization of public security in Mexico (e.g. Alonso 2021; Celis et al. 2020; Garat 2020; Guerrero, 2019; Pérez Correa 2019).

We replicate Atuesta's model and introduce new control variables at the state and the municipal levels to account for the seasonal patterns in violence, drug trafficking, the resource curse (including natural resources) and the presence of multiple DTOs in the Mexican municipalities. After estimating and analyzing the models, we find that these rival processes influence the relative impact that military interventions have on lethal violence. Specifically, we find that PAN rule at the state level is associated with lower lethal violence, while seasonality in violence, competition for scarce resources, and the presence of multiple DTOs are associated with higher lethal violence.

Surprisingly, PAN rule has divergent results depending on the governing level when it comes to military interventions and lethal violence. PAN rule at the state level is associated with lower lethal violence, while PAN rule at the municipality level is not. We suggest that party alternation after 2007 has been less disruptive for criminal activities because DTOs became less dependent on government protection for carrying out their illegal activities. This is also supported by Trejo and Ley (2018) who find that party alternation at the state level motivated drug cartels to create private militias to protect themselves against potential attacks from rival cartels and from

\footnotetext{
${ }^{1}$ It should be noted the seasonality in violence could be considered a particular case of Drug Trafficking Organizations (DTO) competition for scarce resources. However, a similar argument could be made using commodities such as oil and minerals.
} 
incoming opposition authorities. In addition, increased coordination between the federation and state governments might partially account for these results.

Our study makes the following contributions to the literature. First, it suggests that current studies about the effect that military interventions have on violence have an omitted variable bias. Such bias should be addressed to accurately measure the effect that military interventions have on lethal violence. Second, the study improves the research about military interventions and lethal violence by controlling for competing processes that might also be driving the levels of lethal violence in the Mexican municipalities. Third, the manuscript provides a more nuanced view about the causes that are increasing the levels of lethal violence in Mexico. In addition, our approach allows us to holistically compare the contribution that each of these processes make to the level of violence in the country.

We suggest that the literature should give greater attention to the dynamic of competition between DTOs for poppy crop cultivation sites and other valuable resources (e.g. oil, precious metals) to reduce the level of lethal violence in the country. In addition, the Mexican government should recognize the effect on lethal violence that military interventions have, particularly in the municipalities that are highly contested by criminal groups, and work to develop early alarm systems. Finally, we argue that governmental interventions should use less confrontational strategies to reduce the negative consequences associated with military interventions.

Our conclusions become relevant given President Andrés Manuel López Obrador's (AMLO) decision to create a new security force called "La Guardia Nacional" (GN) made up of members of the Armed Forces and the Federal Police, to deal with public security in the country. The "GN" is a security force with police-military features that performs traditional proximity/preventive policing with investigative and penal procedural functions, but also provides assistance with social programs. ${ }^{2}$

Human rights activists have argued that the "Guardia Nacional" and its military traits exacerbate the risk of abusive use of force and continue the militarization that prevailed during the past administrations. News articles and NGOs reports confirm instances of abusive treatment committed by the "NG" (Escamilla-Hamm 2020; Tucker 2020; Fisher, 2020). Nonetheless, the participation of the army in public security persists and has been expanded by AMLO. Our research findings suggest that a better policy option be would be to strengthen civilian security forces instead of expanding the responsibilities of the military and their spheres of action.

\footnotetext{
${ }^{2}$ The GN has a wide range of responsibilities, such as: 1) Traditional proximity/preventive policing with investigative and penal procedural functions. 2) Supporting federal social programs by guarding, transporting, delivering, and distributing assistance in kind and cash. 3) Providing civil protection (GN Plan) during disasters and crises. 4) Supporting local forces and the Mexican Armed Forces (SEDENA and SEMAR FFAA) in special operations. 5) Supporting the search and rescue of kidnapped persons and desaparecidos (victims of enforced disappearance). 6) Conducting criminal intelligence, surveillance activities, and complex investigations about crimes of federal and state jurisdiction. 7) Patrolling strategic infrastructure e.g., airports, highways, federal penal courts, prisons, public plazas, and others. During the COVID-19 pandemic, the GN has protected hundreds of hospitals and health care personnel. 8) Combating organized huachicoleo, the theft of fuel and its sale in the black market by COs. 9) Patrolling border and migration installations; checking documentation; detaining undocumented immigrants; and providing humanitarian assistance. 10) Disrupting illicit supply chains. National guards intercept contraband of illegal firearms, bulk cash, drugs, and other contraband by monitoring package-delivery services, airports, highways, and border areas. Also, they dismantle synthetic drug labs and eradicate illicit fields of marijuana and poppy plants.
} 
The manuscript is structured as follows. The next section provides a review of the literature concerning the effects that military interventions have on lethal violence and describes the mechanisms that explain this association. Then, it introduces other processes identified by the literature that might also be driving this violent behavior in the Mexican municipalities. Section three describes the data and the variables used in the research. Section four explains the empirical strategy of the research and the model used in the study. Section five describes the results of the model. The final section summarizes the findings of the research, provides policy recommendations, and directions for further research.

\section{Review of the literature}

Since Felipe Calderón Hinojosa ${ }^{3}$ started the 'War on Drugs' in 2007, the rates of violence and crime in Mexico increased significantly (Heinle et al. 2015). According to Mexico's National Institute of Geography and Statistics (INEGI), the homicide count "increased from 10,452 in 2006 to 27,213 in 2011 and, in total, more than 50,000 deaths are attributable to the conflict (Basu and Pearlman 2016, p.1). This increase in the levels of violence in Mexico has been directly linked to criminal activities associated with drug trafficking and organized crime. According to Heinle et al. (2015), violence in the country has been characterized by: armed confrontations, mass executions, torture, dismemberment of bodies and pozoleros, use of high-caliber firearms, decapitations, narcomantas, ${ }^{4}$ mass graves, bombings and other methods used by drug traffickers and organised criminal groups (p. 9). Figure 1 describes the increase in the number of homicides in Mexico during the period of 2000 to 2017.

According to the graph, the number of homicides in the country dramatically increased after 2007. These numbers generated intense public debate in Mexico. Some scholars believe that the rise in the levels of violence was caused by the "War on Drugs" declared by the government. In contrast, government officials argue that the levels of violence in the country would have been greater without government intervention (Poiré and Martínez 2011; Valdés Castellanos 2013). Contrary to official rhetoric, most studies find a positive correlation between military interventions and lethal violence in the country. The following section summarises these studies.

\section{Military interventions and lethal violence}

Escalante Gonzalbo (2011b) was the first author who identified an association between military interventions and homicidal violence. By using homicide counts per state and comparing them with the national average, Escalante identifies a correlation between the local murder rates and the military interventions. He concludes that lethal violence skyrocketed in the states where military operations were implemented. Merino (2011) contested this claim by arguing that drug related homicides did not increase in places

\footnotetext{
${ }^{3}$ Calderón was President of Mexico from 2006 to 2012.

${ }^{4}$ Narcomantas are messages left by criminal groups, belonging to a drug cartel, accompanied by attacks and/ or executions in which they try to justify their crimes and send threats to rival groups, police, politicians, businessmen, etc. Pozoleros refer to persons who decompose human bodies, typically in large drums of chemicals.
} 


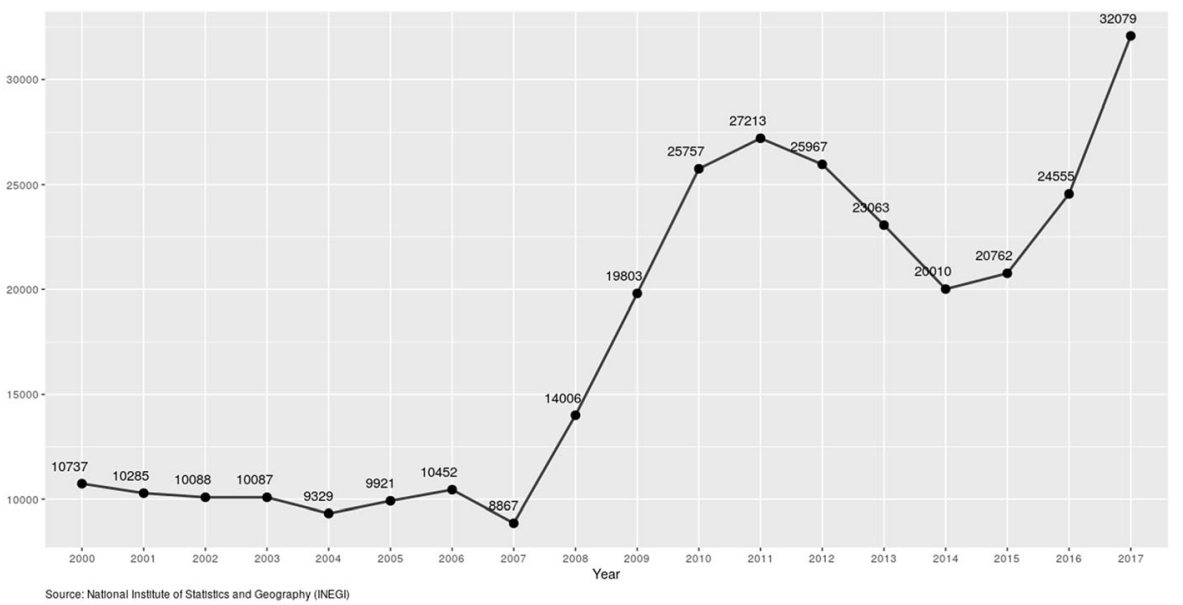

Fig. 1 Number of Homicides in Mexico, 2000-2017. Source: National Institute of Statistics and Geography (INEGI in Spanish)

with military presence in 2007-2010 and homicides rates should behave the same. Escalante replied that Merino analyzed criminal executions, not the local homicide rates, and suggested that they could both be right in their findings. Unsatisfied with this answer, Merino tried to disprove Escalante ${ }^{0}$ s findings in a new article. First, he divided the homicides by types (common crime vs organized crime). Second, he identified which states had joint operatives with intervention of the military and used the others as control. Third, he implemented a matching strategy to isolate the causality between military interventions and lethal violence.

Ironically, Merino's article confirmed Escalante's claim that states where military interventions were implemented experienced higher levels of lethal violence. Merino (2011) finds that the amount of homicides between the states with military operations and the rest of the country increased dramatically after the military operations in Michoacán (December 2006); Guerrero and Baja California (January 2007); Nuevo León and Tamaulipas (January 2008); Chihuahua (April 2008); Sinaloa and Durango (May 2008). Merino's work, however, was not without critics. Rosas (2012) doubted that the matching method used by Merino (2011) allowed him to establish causal inference. First, "the allocation of military interventions to different states was not random, which makes it difficult to interpret any measure of statistical association between" military intervention" and" homicide rate" as a causal relationship" (Rosas, 2012). Second, Rosas highlights that even with matching techniques it is difficult to find control units sufficiently similar to the units treated, especially if the are many determinants of violence. This problem is present in Merino's matching strategy which considers the homicide rate from the previous year as the only relevant variable that determines whether a state will receive a military intervention.

Third, Merino's strategy is prone to omitted variable bias because it is hard to assure that a state's propensity to receive a military intervention was not responding to other factors not considered by Merino. Fourth, Merino's database is highly unbalanced with regard to the distribution of propensities (likelihood of receiving a military intervention) between the observations. For the matching method to work, high risk intervention 
cases need to function as control units for all the treated units that appear in Merino's work. This is not the case as border states are very different from states in south and center of Mexico. Finally, Merino takes the states murder rates across time as independent, when they are serially and geographically correlated. This means that homicide levels within a state depend on the previous period and that the homicides rates in some neighboring states vary jointly. However, Merino's work does not account for any temporal or spatial correlations. For these reasons, Merino (2011) can not conclude that lethal violence increase because of military interventions.

These problems are better dealt with in Atuesta's work. Atuesta (2018) tests whether military interventions increase the number of homicides in the Mexican municipalities. The author uses a hierarchical linear model that accounts for group and time effects in the study units. In addition, Atuesta's model includes controls for population size, poverty, region, criminal group presence and ruling party and takes municipalities as the units of analysis. These are major improvements from previous studies. After running her model, Atuesta finds evidence that military interventions increase violence in the Mexican municipalities. According to the author, one additional confrontation in the municipality with the participation of SEDENA (the Army) increase the number of homicides in the municipality by $8.55 \%$. Similarly, one additional confrontation with participation of federal forces (SEMAR, SEDENA, or the Federal Police) produces, on average, an increase of 3.6\% homicides (Atuesta, 2018, p. 24). Atuesta's research is one among the most robust currently found on the literature because it controls for the characteristics of the states and municipalities where the confrontations occur. This is important because local factors might also explain increases in the levels of lethal violence in the municipalities that had military interventions (Poiré and Martínez 2011; Berber Cruz 2016).

Atuesta (2018) is not the only article that uses a strong identification strategy to test this association. Espinosa \& Rubin (2015) use propensity score matching to generate a quasi-experimental comparison group for municipality clusters that had military interventions. The authors find a positive association between the levels of lethal violence in the municipalities and the military interventions. They estimate that 'the average intervention effect is 5.78 , and its estimated $95 \%$ interval is $(0.29,8.92)$. The lower bound is only slightly above zero, therefore still suggesting that the interventions lead to an increase in homicide rates the year after' (Espinosa \& Rubin, p. 25). However, the authors acknowledge that their method is only slightly better than Escalante's (2011) and Merino's (2011), because they are unable to get random assignment in the treatment variable. This occurs because military interventions are 'not randomised but occurred following some political process' (p. 19).

Additional research identifies mechanisms that explain the association between military interventions and lethal violence. Guerrero (2011) argues that the government's focus on arresting or killing members of criminal organizations generates conflicts within DTOs for the leadership of the organization. Osorio (2015) posits that military interventions weaken incumbent criminal organizations in a municipality which generates incentives for other criminal groups to try to take over their territories. Calderón et al. (2015) suggest that the capture or killing of drug cartel leaders and lieutenants generate 'the deterioration of the chains of command within cartels that discipline local criminal cells, which then opt for increasing criminal behavior against the general population in order to extract additional resources' (Calderón et al. 2015, 
p.1482). Dell (2015) finds that government intervention distorts traffic routes used by criminal organizations which provokes the spread of violence to the neighbouring municipalities. Finally, Atuesta and Ponce (2017) find that 'following security-force intervention, the number of criminal organizations increases, and such greater fragmentation in turn raises the incidence of violence among criminal organizations as the relative power of the organizations changes' (p. 375).

\section{Competitions for opium cultivation sites and crops}

Although the literature finds a positive association between military interventions and lethal violence, it fails to control for alternative hypotheses that also drive the behavior of lethal violence in the territory. These rival hypotheses include 'seasonality in violence', competition among DTOs for strategic sites and resources" and the volume of drug trafficking within a municipality. We begin with the former. According to Lauritsen \& White (2014), 'seasonal patterns exist when similar fluctuations in the victimization rates tend to recur each year during the same season' (Lauritsen \& White, 2014, p. 1). In the Mexican case, the literature finds seasonal patterns in violence during the early spring and late summer after 2006. Phillips (2016) suggests seasonality occurs because drug cartels fight with each to get control of poppy cultivation sites. According to the author, "the logical assumption is that because the opium cultivation areas are constrained, the competition for these areas is more intense. Thus, the seasonal spike in homicides could be a symptom of cartel fighting for the yearly opium harvest' (Phillips 2016, p. 33). In addition, Dube et al. (2013a) find that maize price shocks reduced the wages of farmers in municipalities that were suited for growing maize crops. Successively, households in these municipalities started planting more drug crops (poppy and marijuana) to offset the reduction in income generated by drops in maize prices. In response to this dynamic, drug cartels began to fight with each other to control economically depressed territories where farmers were willing to supply more illicit crops. Dube et al. (2013b) help to explain why municipalities that grow poppy crops are typically more violent than the rest of the country. However, additional violence is generated by the presence of multiple criminal organizations in these locations. Using heroin prices with agro-climatic conditions to grow opium as instrumental variable, Sobrino (2019) finds that cartel presence increases in municipalities well-suited to grow opium poppy after 2010. This occurs because of increased demand for heroin in the United States. The author also finds that local homicides rates increased as competition between cartels increased in the Mexican municipalities.

\section{The resource curse}

Literature finds that states with valuable resources experience longer and more intense civil wars. Collier and Hoeffler (2004), Malone and Berdal (2000), Le Billon (2001) and Fearon and Laitin (2003) associate the existence and duration of civil wars to the presence and exploitation of natural resources by rival parties. According to Le Billon (2001), "resources not only financed, but in some cases motivated conflicts, and shaped strategies of power based on the commercialisation of armed conflict and the territorialisation of sovereignty around valuable resource areas and trading networks" (p. 561). In Sierra Leone, illegal mining and the corruption in the government led to 
civil war and vicious practices carried out by criminal groups against the citizens of the country (Le Billion, 2008). In Nigeria, similar problems arise due to an abundance of oil in the Niger Delta (Boris 2015; Ikelegbe 2005).

Discovery and commercialization of natural resources also attracts criminal groups who seek to control the resources for power or monetary gain (Dube and Vargas 2013; CITpax Observatorio Internacional 2012; Wagner, 2016; Kenny et al., 2020). In Latin America, CITpax Observatorio Internacional (2012) find that cartel leaders dispute the control of minerals and oil producing municipalities in Colombia. The authors suggest this happens because the drastic changes in the price of these commodities made attractive the appropriation of these highly profitable resources by criminal groups (CITpax Observatorio Internacional 2012). Similarly, Dube and Vargas (2013) find that increases in the global prices of gold and petroleum increase the number of casualties associated with the FARC and the paramilitary in Colombia. Dube et al. (2016) find a similar pattern with maize production and drug-related violence in Mexico. Kenny et al. (2020) find that increased demand for oil palm is associated with an increase in violent clashes among armed groups as they compete to control the sectors rents.

The authors of these papers provide different reasons to explain these outcomes. CITpax Observatorio Internacional (2012) posits that as the prices of minerals increased, illegal exploitation of these commodities began to represent a very attractive complement to illicit cultivation or other illegal activities for armed groups outside the law. At the same time, having more mining companies operating in the country and increased profits for multinationals, created more possibilities for criminal groups to capture resources through extortion. Finally, "with the increase in royalties paid by companies in the extracting sector to the Colombian State, the illegal armed actors also increased their resources from the illegal collection of these royalties" (CITpax Observatorio Internacional 2012, p.6). For the case of tungsten, the authors suggest that the appeal of this mineral "resides in the possible benefits derived from the negotiation of an important material for the manufacture of surface-to-air missiles and the production of projectiles capable of damaging armor" (CITpax Observatorio Internacional 2012, p.33).

Natural resources also attract criminal groups because they are easily accessible. "This lootability arises in part from the fact that resources, and in particular extracted ones, are often easily accessible to governments and rebels alike with minimal bureaucratic infrastructure. Another explanation of why criminal groups are attracted to natural resources is that the technology/processes used by these industries create bottlenecks that make rents from these industries easy to capture. For example, Kenny et al. (2020) find that violence in oil palm territories is associated with "the expansive and lightly administered nature of the territory in which oil palm is produced, and the presence of choke points in its supply chain, especially in the areas of harvesting and transportation" (p. 30). Furthermore, resource extraction activities are, to a greater degree than other economic activities, spatially fixed" (Le Billion, 2001, p. 569). Given that these activities cannot be relocated, criminal groups take advantage of companies and employees that work in the extraction and distribution of these resources, by placing extortion on them.

Dube and Vargas (2013) recognize the importance of the resource predation and the looting arguments presented above, but differentiate between the "rapacity effect" and the" opportunity effect". According to the authors, higher wages may lower conflict by reducing labor supplied to the illegal appropriation of resources (the opportunity effect). 
In contrast, the rapacity effect describes the incentives that armed groups have to capture revenues from natural resource to finance their military activities or control the sector's rents. Another reason natural resources attract criminal groups is that "the production and marketing of minerals became less complicated and risky in comparison with the production, transportation and processing of drugs". As the drug markets become more crowded and competitive, mafia-like organizations diversify their portfolio of revenue-generating activities. For example, the efforts of the Colombian State in the last decades in its fight against drug trafficking, the cost and risks associated with this activity increased, it is logical that illegal armed actors seek to compensate their economic losses with other types of activities similarly profitable - like illegal gold mining - but whose product had some freedom of mobility economic in legal markets" (CITpax Observatorio Internacional 2012, p.25). ${ }^{5}$

In the case of oil, Jones and Sullivan (2019) find that Mexico's illicit fuel trade involves drug cartels, huachicoleros, and corrupt government (and PEMEX) officials. According to the author, "Petro-theft is a component of criminal resource extraction that fuels the capacity and fills the coffers of criminal cartels. Threats to pipelines and processing facilities inhibit legitimate refinery and distribution operations while opening opportunities for criminal gangs and cartels to fill the vacuum of legitimate petrol distribution" (Jones and Sullivan 2019, p. 5). In Mexico, some municipalities have easy access to oil pipes which make them prone to capture by criminal groups. For these reasons, we expect that municipalities that have oil pipes will have higher levels of violence than their counterparts.

\section{DTOs competition}

Another hypothesis that explains the increased levels of lethal violence after 2006 is DTOs competition. Ríos (2015) posits that competition between DTOs generates 'a selfreinforcing equilibrium in which incremental increases in traffickers' confrontations raise the incentives of the government to prosecute traffickers which promote further confrontations with traffickers' (p. 1). Pereda (2018) argues that extreme competition between criminal organizations can generate a process of continuous violence escalation that is difficult to stop once started. According to the author, by 'using increasingly violent actions intended to deter competitors and government forces, criminal organizations sometimes eliminate their exit option, making the penalties for withdrawal to a less violent strategy significantly worse than those of continued violence' (Pereda 2018, p. 63). The author identifies this dynamic of extreme violence escalation only for 'La Familia Michoacana' and 'Los Caballeros Templarios' after 2008, but a similar dynamic might also be found between 'Zetas' and 'El Cartel del Golfo', 'Zetas' and 'El Cartel de Sinaloa', and between 'El Cartel de Sinaloa' and 'Beltran Leyva'. Finally, Atuesta and Ponce (2017) find that the greater fragmentation of criminal organizations after a military intervention raises the incidence of lethal violence among criminal organizations.

\section{Drug trafficking}

Drug trafficking in a municipality is also associated with higher levels of lethal violence (Goldstein, 1985). Calderón et al. (2015) argue that municipalities located in strategic

\footnotetext{
${ }^{5}$ This may also have happened in Mexico after president Calderon started the "War on Drugs".
} 
points (valuable plazas) or near the transportation network are particularly valuable and hence vulnerable to turf wars. In addition, the authors find that these locations experience sharp increases in violence after the government captures or neutralises drug cartel leaders and lieutenants. Dell (2015) finds that government intervention distorts trafficking routes used by criminal organizations which provokes the spread of violence to the neighboring municipalities. According to the author, 'this violence reflects rival traffickers' attempts to wrest control of territories after crackdowns initiated by PAN majors have weakened the incumbent traffickers' (Dell 2015, p. 1740). Surprisingly, few studies account for the impact that drug trafficking has on the level of lethal violence in the Mexican municipalities (Dell 2015). We believe this happens for two reasons. First and foremost, data about drug trafficking at the municipal level is not publicly available. Second, research from the period before the 'War on Drugs' started suggests that drug trafficking is not related to widespread lethal violence in the country (Astorga 2005a; Valdés Castellanos 2013). ${ }^{6}$ We believe this changed after 2007, when drug trafficking became actively prosecuted by the government and DTOs became more numerous and competitive.

\section{Party alternation}

The literature associates the supplanting of political parties at the gubernatorial and municipal levels with the breakdown of informal networks of protection for criminal groups. (Astorga 2005b 2010; Dube et al. 2013b; Ríos 2015; Trejo and Ley 2018). Villarreal (2002) posits that the Mexican democratic transition increased violence by disrupting established patronage networks between PRI's politicians and criminals. Dube et al. (2013a) find that municipalities with a larger number of effective political parties contesting elections experienced higher levels of lethal violence than their counterparts. The authors suggest that electoral competition jeopardised the cartels access to informal protection networks that were provided by the municipal police. Other authors argue that democratization changes the behavior of the government agencies. Osorio (2015) suggest that increased democratization leads to greater law enforcement and that greater law enforcement leads to greater violence among drugtrafficking organizations.

Party alternation also influences the coordination and access to resources between different government levels. Ríos (2015) argues that democratization at the state and local level "affected the capacity of the state to contain the emergence of cocaine markets because it affected coordination and cooperation between different levels of government" (p. 2). Duran-Martinez (2015) argues that violence intensifies when trafficking organizations compete and the state security apparatus is fragmented. Trejo and Ley (2018) find that "local authorities are more likely to become targets of criminal attacks in sub-national regions where political power is more vertically fragmented" (p. 10). They also suggest that municipal governments from non-PAN parties were targeted by criminal organizations because they did not have military support from the federal government.

\footnotetext{
${ }^{6}$ On this regard, Thoumi (2010) argues that 'Mexico, has had drug trafficking for a century, and while there were individual cases of murder associated with drugs, the illegal drug industry was relatively peaceful' ( $\mathrm{p}$. $38)$.
} 


\section{PAN rule}

Other studies find that the arrival of PAN administrations at the sub-national level is associated with more lethal violence in the Mexican municipalities. Dell (2015) finds that violence increased after mayors from the conservative National Action Party were elected to office. According to the author, this was due to "rival trafficker attempts to wrest control of territories after crackdowns initiated by PAN mayors have weakened the incumbent traffickers" (p. 2). A similar argument is provided by Osorio (2015). Trejo and Ley (2018) find that party alternation at the state level motivated drug cartels to create private militias to protect themselves against potential attacks from rival cartels and from incoming opposition authorities. Typically, these new governments were PAN governments.

\section{Motivation of current study}

Existing research clearly demonstrates a strong relationship between military interventions and levels of lethal violence in Mexico (e.g. Atuesta 2018; Espinosa \& Rubin, 2015). However, some of the extant research relies on flawed methodological strategies or identification methods, as we have noted. Further, research testing for an empirical association between violence and military intervention has largely failed to control for alternative hypotheses. Chief among these alternative explanations are the seasonal patterns in violence, DTO competition for scarce resources (i.e. opium crop), and the volume of drug trafficking.

In this study, we propose an empirical test to understand the contribution of these understudied competing processes that we hypothesise also drive lethal violence. It is our intention to build on established models of violence, extending them to incorporate new variables that in turn allow for the model to account for competing explanations. Our study should help us understand whether these competing explanations attenuate or mitigate the effects of military interventions, which have been shown to be strongly related to lethal violence. Ultimately, our aim is to put forth a single empirical model that captures with high fidelity the various interrelated processes that simultaneously drive lethal violence in Mexico.

In subsequent sections, we review the multiple data sources used in our model before discussing the model itself and the results of our empirical analyses. We conclude with a discussion of these results and their policy implications.

\section{Description of the data}

To test our hypotheses, the empirical analysis relies on four different datasets. First, the data on homicides of young males, demographics, mineral production, and the presence of oil pipelines in the Mexican municipalities are taken from INEGI. Second, data on confrontations between criminals and government forces and the number of criminal groups present in a municipality are gathered from the CIDE-PPD Dataset. Third, data on ruling political parties in the municipalities and in the states during the study period are generated from the CIDAC database of elections in Mexico. Finally, data about the 
states and municipalities that produce heroin, and the months of poppy crop harvesting is taken from Phillips (2016) and from the army records. The sources of the data are described below.

\section{The INEGI dataset}

The National Institute of Statistics, Geography and Informatics (INEGI) is an autonomous public body responsible for disseminating information about the territory, resources, population and economy in Mexico to help decision making. It is independent of any law enforcement agency and provides mortality data, including deaths by homicide and other forms of violent crime, dating back to 1990. The INEGI database has been used regularly to assess the impact that military interventions have on lethal violence (Escalante, 2011; Espinosa \& Rubin, 2015; Atuesta 2018).

\section{The CIDE-PPD dataset}

The CIDE-PPD Dataset records violent events that took place between December 2006 and November 2011 (Atuesta et al. 2019, p. 7). It gathers more than 36,000 events of drug related violence. The CIDE-PPD dataset contains information about confrontations, executions, and aggressions between governmental forces and criminal organizations as well as the casualties generated in those confrontations (Atuesta et al. 2011). The CIDE-PPD database has been used to study messages in narcomantas left by DTOs (Atuesta 2017), DTOs geographical areas of influence (del Fuerte Celis 2016), violence against journalists (Guerra 2016), the effect of the governmental intervention in the rise of violence in Mexico (Atuesta and Ponce 2017), and the effect that drug related violence has on the mental health of indirect victims of violence (Flores and Atuesta 2018).

\section{The CIDAC database}

The CIDAC Electoral Database compiles the data for all the levels of government (federal, state and municipal) in a period of 25 years. The database includes the INEGI identification number for each geographical unit, which facilitates the merging of the electoral information with other databases. In addition, the information is presented in a format that details the electoral operation of the different political parties, such as the electoral coalitions and their hierarchy in each election since 1985. The database is based on the district computations of the National Electoral Institute (INE in Spanish).

\section{The Army records}

Data about the municipalities that grow illegal crops and drug trafficking is taken from the Army (SEDENA) records. Specifically, we requested data about the number of kilograms of cocaine and marijuana seized by SEDENA per month to use as a proxy of the amount of drug trafficking in a municipality. Similarly, we requested data about poppy drug eradication per month to identify the municipalities that are heroin producers. 


\section{The dependent variable}

The dependent variable in subsequent models is the homicide rate of young males (1529 years old) per month that took place in a municipality in the period of 2007-2011, and were taken from the INEGI database. Our primary focus in this paper is on the drivers of lethal violence in Mexico, which principally revolve around military intervention to the illicit drug trafficking trade. Although we have data on the total number of homicides (as well as the homicide rate) in municipalities in Mexico for the same time frame, not all of these homicides were drug-related, and the data do not allow for a precise identification of which homicides were drug-related and which were not. To focus more narrowly on lethal violence that is most likely related to drug trafficking, we selected the young male homicide rate as our endogenous variable, as this is the population most likely to be involved in the illicit drug trade.

\section{The explanatory variables}

The variable 'combats with participation of SEDENA (lagged)' registers the number of confrontations with participation of SEDENA (the Mexican Army) that took place in a municipality in the previous month. The variable 'heroin producer municipality' registers if a municipality is a known heroin producer. The variable 'heroin producer state' registers if a municipality is located in a state that is a heroin producer. The variable 'number of criminal groups' registers the number of DTOs present in a municipality. The variable 'tons of drugs trafficked in the municipality (lagged)' registers the number of tons of cocaine and marijuana seized by the army in a municipality in the previous month. The variable 'municipality with oil pipeline' registers if a municipality has an oil pipeline. The variable 'tons of precious metals produced' registers if a municipality produces gold or silver.

\section{The controls}

Control variables include the $\log$ of the municipal population, the percentage of the population living in poverty in 2005 , the average homicide rate of young males in the neighboring municipalities, dichotomous variables for the location of the municipality (if it is on the Pacific coast, on the border with the US, or in the Gulf of Mexico), two dichotomous variables that register if the municipality has a government from the Party of National Action (Partido Acción Nacional in Spanish, or PAN) in the municipality or in the state during the study period. The variable "urban" registers if a municipality has more than 2500 inhabitants. The variable "Tax revenue per municipality (logged)" is the log of the yearly tax revenue per municipality. We include this variable as a proxy for state capacity. The following section describes the model specification.

\section{Statistical model}

We estimate mixed effects linear regressions to examine the associations between the variables that may be driving the behavior of lethal violence in the Mexican

\footnotetext{
${ }^{7}$ Calderón's political party.
} 
municipalities. We choose random-effects per state and municipality to account for the nested structure of the municipalities within states and for variation across the municipalities for unidentified local factors. We also use random-effects because some of the key independent variables and controls in our models do not vary for several consecutive years. The general model is described below:

$$
Y_{i t}=\beta_{0}+\alpha_{i}+\beta_{i} E_{\mathrm{it}-1}+\mathrm{P} \beta_{k} X_{i t k}+v i t
$$

where $\left(\mathrm{Y}_{\mathrm{it}}\right)$ is the homicide rate of young males reported by the INEGI in the municipality $i$ in the period $t, \alpha$ are fixed effects by state and year for the municipality $i, \mathrm{E}_{\mathrm{it}-1}$ is the variable used to measure the presence of a military intervention in the municipality $i$ in the period $t-1, \mathrm{X}_{\mathrm{itk}}$ are control variables included in the model that help explain the behavior of the homicide rate. These variables include the percentage of the population living in material poverty, the average homicide rate of young males in the neighbouring municipalities, dichotomous variables for the location of the municipality $i$ (on the Pacific coast, on the border with the US, or in the Gulf of Mexico), the log of the yearly tax revenue per municipality and population size (the municipality is urban). Lastly, $v_{i t}$ is an error term.

We include new variables in the general model to test rival hypotheses. These variables include two dichotomous variables that register if the municipality has a government from the PAN in the municipality or in the state during the study period. In addition, we include a variable that registers the presence of DTOs in a municipality. We also include variables that measure for the presence of valuable resources like oil pipes and precious minerals and if the municipality is located in a state that is a heroin producer and if it grows poppy crops (Model 5). Finally, we include a variable that registers the volume of trafficking in a municipality in the period before any military intervention occur (Models 3). The following section describes our results.

\section{Results}

Table 1 shows the results of the mixed effects linear regressions for varying specifications. Column 1 models the influence of military interventions on the young male homicide rate by municipality without including any alternative hypotheses. Column 2 adds the number of criminal groups identified in a municipality to the model. Column 3 presents the model used by Atuesta (2018) to measure the impact that military confrontations have on lethal violence controlling for PAN rule. ${ }^{8}$ Column 4 adds a variable that registers the volume of drug trafficking (lagged one period) in the municipality. Column 5 includes a variable that accounts for the presence of precious metals in a municipality. Column 6 incorporates a variable that measures the presence of an oil pipe in a municipality. Column 7 incorporates the variables related to the seasonality of violence hypothesis. In this column one variable measures whether the

\footnotetext{
${ }^{8}$ In contrast to Atuesta (2018), our model is not aggregated by quarters. We also removed the lagged dependent variable from the model specification. The use of a lagged dependent variable in the regression model is problematic because it causes the coefficients for explanatory variables to be biased downward. Finally, the model includes the tax revenues variable as a proxy for state capacity.
} 


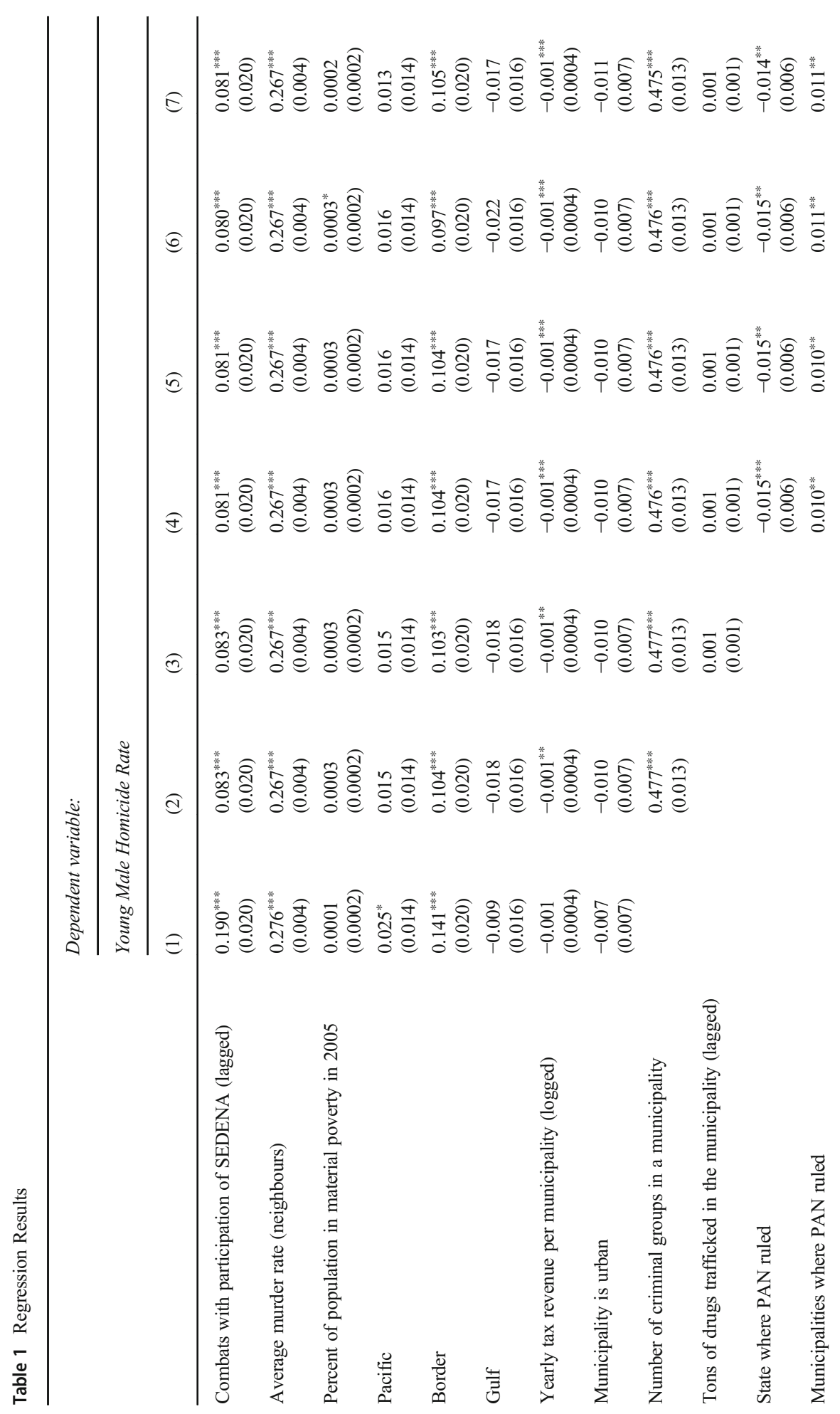




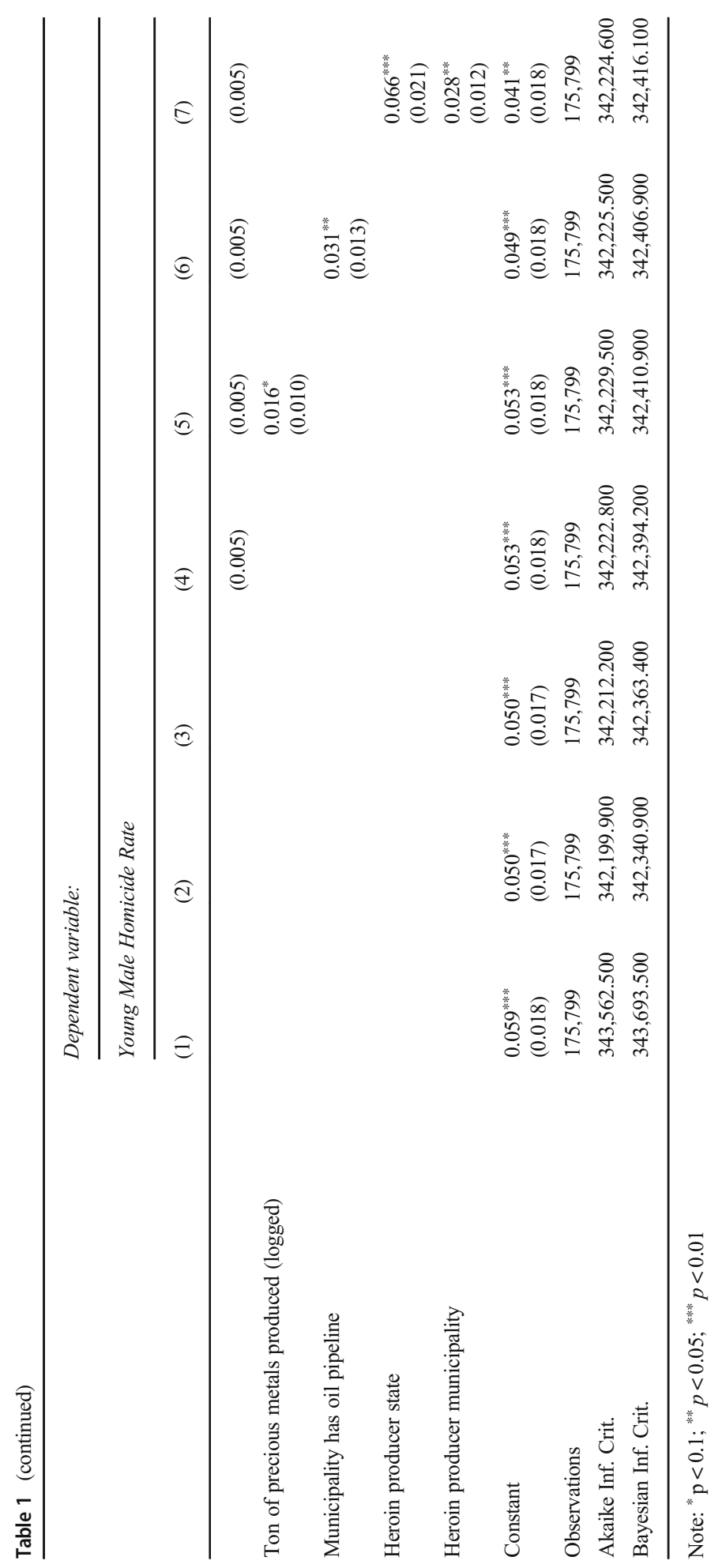


municipality is located in a state that is a heroin producer and another variable measures if the municipality grows poppy crops.

In all specifications, control variables are included that help explain the behavior of (young male) homicides in the Mexican municipalities. These variables include the percentage of population living in material poverty in 2005, the average murder rate of young males in the neighboring municipalities, the geographic location of the municipality (if the municipality is located in the Pacific coast, in the border with the United States or in the Gulf of Mexico), the yearly tax revenue per municipality, a dummy that registers if the municipality is urban, and year and state fixed effects. All model specifications include random effects at the municipal level (Table 2).

Results suggest that one additional confrontation with participation of SEDENA in the municipality increases the homicide rate of young males by $19 \%$ (Column 1). However, the coefficient decreases to $8.3 \%$ units when the number of criminal groups is added to the model (Column 2) and include drug trafficking to the model (Column 3), 8.1 when we control for PAN rule at the state and municipality levels (Column 4), and control for the municipalities that have precious metals (Column 5), 8\% when we control for the presence of an oil pipe in the municipality, and $8.1 \%$ when we account for seasonality of violence (Column 7). Most of the controls included in the model behave as expected. A one unit increase in the average murder rate in the neighboring municipalities increases violence by 0.276 units in all model specifications. In contrast, a $1 \%$ increase in the percentage of population in material poverty in 2005 , is predicted to increase the murder rate in a range between $0.001 \%$ to $0.003 \%$ depending on the model specification. However, this variable is not statistically relevant at $95 \%$ confidence in any model specification.

Table 2 Descriptive Statistics

\begin{tabular}{|c|c|c|c|c|}
\hline Variable & Mean & Std.Dev & Min & Max \\
\hline Young male average murder rate (neighbours) & 0.07 & 0.36 & 0 & 56.43 \\
\hline Border & 0.01 & 0.12 & 0 & 1 \\
\hline Tons of drugs trafficked in the municipality (lagged) & 0.06 & 1.22 & 0 & 135.95 \\
\hline State where PAN ruled & 0.22 & 0.41 & 0 & 1 \\
\hline Number of criminal groups in a municipality & 0.02 & 0.13 & 0 & 4 \\
\hline Gulf & 0.02 & 0.15 & 0 & 1 \\
\hline Yearly tax revenue per municipality (logged) & 11 & 5.51 & 0 & 20.89 \\
\hline Young male murder rate & 0.07 & 0.65 & 0 & 112.87 \\
\hline Municipality has oil pipeline & 0.04 & 0.2 & 0 & 1 \\
\hline Pacific & 0.03 & 0.16 & 0 & 1 \\
\hline Municipalities where PAN ruled & 0.15 & 0.36 & 0 & 1 \\
\hline Percent of population in material poverty in 2005 & 62.8 & 18.5 & 0 & 96.8 \\
\hline Heroin producer municipality & 0.02 & 0.15 & 0 & 1 \\
\hline Ton of precious metals produced (logged) & 0.02 & 0.18 & 0 & 4.63 \\
\hline Combats with participation of SEDENA (lagged) & 0.01 & 0.08 & 0 & 1 \\
\hline Heroin producer state & 0.37 & 0.48 & 0 & 1 \\
\hline Municipality is urban & 0.85 & 0.36 & 0 & 1 \\
\hline
\end{tabular}


Being located in the Pacific coast is predicted to increase the young male homicide rate in the municipality by $2.5 \%$ (Column 1 ) at $p<0.1$. However, the variable loses statistical relevance when we account for alternative hypotheses (Models 2 to 7). Surprisingly, being located on the border is predicted to increase the murder rate in a range between $14.1 \%$ (Column 1) to $9.7 \%$ (Column 6) depending on the model specification.

In contrast, being located in the Gulf of Mexico is not statistically relevant. One unit increase in the log of the yearly tax revenue per municipality is predicted to reduce lethal violence by $0.1 \%$ in all models, except for the one we use as a baseline (Column 1). Having a urban municipality is not statistically relevant in any model specification.

Interestingly, we find mixed results that PAN rule is associated with more lethal violence in the municipalities. According to our model, being ruled by PAN at the state level decreases the young male murder rate by $1.5 \%$ (Column 4,5 and 6), and $1.4 \%$ (Column 7). Paradoxically, being ruled by PAN at the municipal level increases the levels of lethal violence in all the models. According to our model, municipalities that are ruled by PAN are predicted to have between $1 \%$ (Column 4 to 6 ) to $1.1 \%$ (Column 7) more lethal violence against young males depending on the model specification. Our results suggests that the process of party alternation at the state level after 2007 has been less disruptive for criminal activities because DTOs have become less dependent on government protection for carrying out their illegal activities. This is supported by Trejo and Ley (2018) who find that party alternation at the state level motivated drug cartels to create private militias to protect themselves against potential attacks from rival cartels and from incoming opposition authorities. ${ }^{9}$ In addition, increased coordination between the federation and state governments might partially account for these results.

We do not find confirmation that the volume of drug trafficking increases the young male homicide rate in a municipality. According to our models, this variable is not statistically relevant. This outcome might be explained by the fact that our variable does not account for the trafficking of opium and synthetic drugs. In contrast, we find confirmation for the 'seasonality in violence' hypothesis. According to the model shown in Column 7, being located in a state that is a heroin producer increases the young male homicide rate in the municipality by $6.6 \%$ (Column 7). Likewise, being a municipality that grows poppy crops is predicted to increase violence in a municipality by $2.8 \%$ (Column 7 ).

To test if accounting for a resource curse increases the young male homicide rate, we create a model that accounts for the presence of precious minerals and petroleum (Column $5 \& 6$ ). We expected to find that the municipalities with valuable resources are more violent than their counterparts. Results from Column $5 \& 6$ confirms our expectation. According to the model, having precious metals in a municipality is predicted to increase the young male homicide rate by $0.016 \%$ (Column 5) but only at $90 \%$ confidence. Consistent with our hypothesis, having and oil pipeline in the municipality is predicted to increase the young male homicide rate by $3.1 \%$ (Column 7).

One of our primary assertions in this study has been that the contributions of drug trafficking, the resource curse, seasonality in violence in Mexico, DTO's competition, and PAN party rule are unique from the impact of military intervention. The results of

\footnotetext{
$\overline{9}$ This process started since the year 1990.
} 
our models support this assertion. The coefficient for military intervention retains statistical significance in each model, even after the introduction of multiple variables associated with these alternative hypotheses. We acknowledge that the size of the coefficients drops dramatically from Model 1 to Model 2. To test whether this decrease is statistically significant, we employ a test for differences in effect size put forth by Paternoster et al. (1998), and used in Phillips (2016). The formula for calculating the test statistic is

$$
z=\frac{b_{1}-b_{2}}{\sqrt{S E_{1}^{2}}+S E_{2}^{2}}
$$

where $b_{1}$ and $b_{2}$ are the coefficients being compared, and $S E_{1}$ and $S E_{2}$ are the standard errors of the two coefficients, respectively. This test is distributed as $z$ with degrees of freedom equal to one less than the sample size. We calculate this test with each pair of coefficients for military intervention (i.e., Model 1 and 2, Model 2 and 3, Model 3 and 4, Model 4 and 5, Model 5 and 6, and Model 6 and 7) to determine if the inclusion of additional variables significantly reduces the effect size. ${ }^{10}$ In only one case do we reject the null hypothesis of equal effect sizes; the coefficient is significantly reduced in size between Model 1 and 2. The introduction of the variable accounting for the number of criminal groups involved in a given municipality reduces the impact of military intervention on the young male homicide rate. This implies shared variation between SEDENA combats and the number of criminal groups (thus, empirical commonality between military interventions and DTO competition). However, even after partialling out this shared variation, both variables make significant contributions to the models, supporting the argument that DTO competition is a key driver of lethal violence. In all other cases, we fail to reject the null hypothesis of equal effect sizes and conclude that the differences in the sizes of the coefficient are not statistically significant. We therefore conclude that the difference in the effect sizes for the military intervention coefficients is not significant once the number of criminal groups has been accounted for in the model. This conclusion in turn suggests that DTO competition is a key driver of violence in Mexico, rather than merely being redundant to military intervention, in addition to the unique contributions of the resource curse, the seasonality of violence, and PAN party rule.

\section{Discussion}

Since the Mexican government initiated the "War on Drugs" the crime and violence rates in Mexico have increased significantly (Heinle et al. 2015). The drastic increase in crime and lethal violence has been associated with military interventions. In this regard, several authors have demonstrated that the number of DTOs and criminal organizations dramatically increased over the last fourteen years, partially driven by the military interventions and the internal fractionalization that ensued. This fractionalization has resulted in a situation in which more criminal organizations are competing in the same

${ }^{10}$ The $\mathrm{z}$ scores for these tests were $z=3.783, z=0.000, z=0.071, z=0.000, z=0.035$, and $z=-0.035$ respectively. 
drug markets. Existing research demonstrates that competition among criminal groups increases violence (Brantingham et al. 2012; Yashar 2018), including those in Mexico (Duran-Martinez 2015; Villarreal 2002). Moreover, criminal groups in Mexico have demonstrated an ability to move from one illicit resource to another, such as oil (Jones and Sullivan 2019) or even wildlife (Ford 2021). These more specialized resources may have lower levels of inter-group competition compared to drugs. Thus, there are varying possibilities regarding how competition for drugs and other illicit resources might influence the levels of violence in Mexico. ${ }^{11}$ However, the literature about military interventions have not incorporated this dynamic of competition between DTOs for drug trafficking routes and resources.

In this study, we argue that research on the "War on Drugs" has identified multiple processes that explain the radical increase of lethal violence in the country after 2007. The competition hypothesis posits that DTOs fight with each other during the months of poppy crop harvesting to secure poppy crop cultivation sites. The other competing processes suggest that DTOs' competition and rivalry, the resource curse and party alternation also influence the levels of lethal violence in the Mexican municipalities. We formulated a model suggested by the literature to test if these rival hypotheses reduce the impact that military interventions have on lethal violence. Our models provide confirmation that these rival hypotheses influence the relative impact that military interventions have on lethal violence.

First, we find confirmation for the 'seasonality of violence hypothesis'. According to our models, being located in a heroin producing state is predicted to increase lethal violence against young males in the municipality by $6.6 \%$. Similarly, being a municipality that grows poppy crops increases lethal violence by $2.8 \%$. In other words, heroin producer states and municipalities that grow poppy crops are typically more violent than their counterparts. However, additional violence is created by the competition between DTOs for these scarce resources. This is confirmed by our third, fifth, and sixth models, which account for tons of drug trafficked, tons of precious metals produced, and the presence of oil pipelines, respectively. In each of these models, additional resources are correlated with higher levels of lethal violence against young males.

Dube and Vargas (2013) find that maize price shocks reduced the wages of farmers in municipalities that were suited for growing maize crops. Subsequently, households in these municipalities started planting more drug crops (poppy and marijuana) to offset the reduction in income generated by drops in maize prices. Dube et al. (2013a) suggest that in response to this dynamic, drug cartels began to fight with each other to control economically depressed territories where farmers were willing to supply more illicit crops. However, additional violence is generated in these territories by the presence of multiple criminal organizations in these locations. These results have important implications. The government should focus their attention on these municipalities and develop early alarm systems that signal DTOs' competition for these scarce resources.

We fail to find evidence that drug trafficking is a driver of lethal violence in the Mexican municipalities. However, this estimate doesn't include information about the volume of opium and synthetic drugs (e.g. methamphetamine) trafficked in the municipality. Therefore, we should expect that the influence of drug trafficking in lethal

\footnotetext{
${ }^{11} \mathrm{We}$ are grateful to an anonymous reviewer for comments on the precision of this issue.
} 
violence in a municipality is greater than what is reported in our model. We believe that government intervention and increased interdiction policies have altered the dynamic of drug trafficking in the country by generating more competition between criminal organizations and distorting transportation routes. Consequently, drug trafficking in a municipality has become a highly contested activity that should be associated with more lethal violence in the territory.

We find evidence that PAN rule at the state level is associated with lower lethal violence, while PAN rule are the municipality level is not. We suggest that party alternation at the state level has been less disruptive for criminal activities after 2007 because DTOs became less dependent on government protection for carrying out their illegal activities. In addition, increased coordination between the federation and state governments might partially account for these results. Lastly, we find that accounting for these rival processes influences the relative impact that military interventions have on lethal violence. In Model 1, one additional confrontation with the participation of SEDENA in the municipality increases the number of homicides by $19 \%$ (Column 1). However, the coefficient drops to $8.3 \%$ when we account for the volume of drug trafficking in the municipality (Column 3), to $8.1 \%$ (Column 4) when we account for 'seasonality of violence' and multiple DTOs present in the municipality. As noted above, in only one case was the reduction in effect size statistically significant. These results are important in terms of policy implications because they suggest that other forces besides military interventions are driving the levels of lethal violence in the Mexican municipalities. Further research on the subject should account for DTOs competition for drug trafficking routes and scarce resources (like poppy crop cultivation sites) to accurately measure the impact that military interventions have on lethal violence.

\section{Conclusions and policy implications}

It has been more that fourteen years since the administration of Felipe Calderón implemented a militarised strategy against the DTOs in Mexico. However, violence is far from receding in the country. On the contrary, it rose to unprecedented levels while the cartels fractured and multiplied. Military interventions have increased the number of players in the drug market and have exacerbated competition between criminal groups. Interdiction policies have complicated the drug trafficking business which has led to the diversification of criminal activities. Moreover, the black market for illicit drugs remains extremely profitable, and when the state weakens any of the groups that controls the local market or the drug transit routes to the United States, other groups seek to fill the power vacuum and replace the existing leaders. This leadership replacement usually happens violently. In addition, reports from the National Human Rights Commission have documented the use of torture and degrading treatment by the police, armed forces, and prosecutors to obtain confessions and testimonies through coercion (Open Society 2016). These data should be reason enough to worry about the way in which security forces contain violence, even if one is not directly involved in illegal activities.

The negative consequences of the "militarization" of security in the country have been greater than the benefits and the desired security improvements have not yet been realised. Violence in Mexico continues to reach record highs. 
Drug related homicides alone topped 33,000 in 2018 (Council on Foreign Relations, n.d.), and homicides continued to climb through 2019 and 2020, setting new records each year (Agren 2020; Al Jazeera 2020). Under new President Andrés Manuel López Obrador (AMLO), Mexico has established a National Guard intended to function as a sort of militarized police. However, the fledgling institution has not yet paid dividends (Agren 2020).

This new force is a blending of military and civilian police, and was proposed as a step toward more professional policing in Mexico. It has been heavily criticized as nothing more than a continuation of the militarization policies of AMLO's predecessors, Calderon and Peña Nieto (Agren 2018; Escamilla-Hamm 2020; Tucker 2020), or redundant to existing agencies (Escamilla-Hamm 2020). Although intended to bring a larger civilian presence to the policing landscape, the National Guard is staffed primarily by military personnel. It has also been criticized on the basis of human rights violations (Tucker 2020), similar to other military organizations in Mexico. Since the creation of this new National Guard, spending on security has been reduced to its lowest level in decades (Agren 2020), and national security law reforms implemented in late 2020 limit the operations of foreign law enforcement in Mexico, such as the US Drug Enforcement Agency (Asmann 2020).

A more effective security policy would focus on avoiding the imbalance of the status quo so as not to generate more violence; decrease the potential profits from the sale of illicit drugs, avoid disrupting drug trafficking routes, and consider that military interventions increase violence in highly contested municipalities and municipalities with predatory criminal governance types. An alternative to greater and greater militarization would be making sincere investments in the civilian security forces. It appears that this may have been some of the intention behind the new National Guard, but this larger civilian police force has not been brought to fruition.

Future studies should also analyze policies that could regulate or mitigate DTO competition for scarce resources. A soft approach might include strengthening the presence of the police in the municipalities and creating a legal market for illegal crops. Governmental interventions should include less confrontational strategies and less participation from the army to reduce the negative consequences associated with military interventions.

We hope these results highlight the need to conduct additional research, and to develop a more nuanced understanding of the processes that are driving the increase in the levels of lethal violence in Mexico to alarming levels after 2006.

\section{Limitations of the study and directions for further research}

The empirical strategy shown here has three main limitations. First, the outcome variable is measured by the young male homicide rate in a municipality. Although we selected this measure as the endogenous variable because males between the ages of 15 and 29 make up the bulk of the illicit drug trade, the data do not permit the separation of drug-related homicides from non-drug-related homicides. Future studies would greatly benefit from an analysis of purely drug-related homicides, if such were data were available.

Second, a more complete model would incorporate additional data on drug trafficking in the municipalities. Specifically, such data would include information about the 
trafficking of opium and synthetic drugs (e.g. methamphetamine). In future work, we plan to address this limitation. We are seeking information on the trafficking of opium and synthetic drugs from SEDENA and SEMAR through a public act of information request. These data will then be integrated into models as additional controls. In addition, we need data about the level of SEDENA deployment in the municipalities. Similarly, we need data about DTOs presence at the municipality level after 2010. The CIDE-PPD database only covers the period from 2006 to 2011 . We need better data to analyze the consequences of DTOs fractionalization and its impact on lethal violence.

Third, our study is limited in its ability to address concerns of reverse causality. In particular, a more robust identification strategy could be proposed to identify more effectively treatment effects. Alternatively, an instrumental variable approach might be useful to account for endogeneity between the variables. Finally, placebo tests could be run to discount the potential for model specification to determine our results. However, the largely stable results we found across the model specification leads us to have confidence that our choice of modeling strategy did not influence the outcomes. We also ran a variety of other specifications, which were not shown, but yielded the same conclusions (hierarchical negative binomial regression). Additional data should allow for further robustness tests and more sophisticated identification strategies.

\section{Declarations}

Ethical approval This article does not contain any studies with human participants or animals performed by any of the authors.

\section{Informed consent Not applicable.}

Conflict of interest The authors declare that they have no conflict of interest.

\section{References}

Agren D (2018) 'Mexican president-elect's new plan to fight crime looks like the old plan." The Guardian. Retrieved from https://www.theguardian.com/world/2018/nov/21/presid elect-amlo-pledges-newmilitary-force-fight-crime-mexico

Agren D (2020) "Mexico murder rate reaches new high as violence rages amid Covid-19 spread." The Guardian. Retrieved from https://www.theguardian.com/world/2020/apr/03/mexicmurder-rate-homicidecoronavirus-covid-19

Al Jazeera (2020)." Mexico murder rate hits record high in 2019.” Retrieved from https://www.aljazeera.com/ news/2020/1/21/mexico-murder-rate-hits-record-high-in-2019

Alonso R (2021) 'Militarismo, poder en expansión.” En Lado B. Retrieved from https://www.ladobe.com.mx/ 2021/01/militarismo-poder-en-expansion/

Asmann P (2020). "What do security law reforms mean for US-Mexico organized crime fight?" insight crime. Retrieved from https://www.insightcrime.org/news/analysis/usmexico-security-law-reform/

Astorga L (2005a) El siglo de las drogas: El narcotráfico, del Porfiriato al nuevo milenio. Random House Mondadori, Mexico City

Atuesta L, Ponce A (2017) Meet the Narco: increased competition among criminal organisations and the explosion of violence in Mexico. Global Crime 18(4):375-402

Atuesta L (2017) Las cuentas de la militarizacio'n. Nexos (1 Marzo). https://www.nexos.com.mx/?p=31552

Atuesta L. (2018). Militarization of the fight against drug trafficking: military operations as strategy for the fight against organized crime (translated from Spanish) in Las violencias: en busca de la poltica pública detrás de la guerra contra las drogas, Edition: Coyuntura y Ensayo 
Atuesta LH, Siordia OS, Lajous AM (2019) The war on drugs in Mexico: (official) database of events between December 2006 and November 2011. Journal of Conflict Resolution 63(7):17651789-17651789. https:// doi.org/10.1177/0022002718817093

Atuesta L, Ponce A (2012). Cómo las intervenciones de las fuerzas públicas de seguridad alteran la violencia. Evidencia del caso mexicano. Cuadernos de Trabajo del Monitor del Programa de Política de Drogas, CIDE-PPD, p. 1-41

Atuesta L et al. (2011). La 'Guerra Contra las Drogas' en M'exico: registros (oficiales) de eventos durante el periodo de diciembre de 2006 a noviembre de 2011, Cuadernos de Trabajo del Monitor del Programa de Política de Drogas, CIDE-PPD, p. 1-77

Astorga L (2005b) El siglo de las drogas [the century of drugs]. Plaza y Jans, Mexico City

Astorga, L., Shirk, D. A. (2010). Drug trafficking organizations and counter-drug strategies in the U.S.Mexican context (working paper series). Washington, DC: Mexico institute

Basu S, Pearlman S (2016). Violence and Migration: Evidence from Mexico's Drug War (July 5). Available at https://doi.org/10.2139/ssrn.2369411

Berber Cruz MA (2016). Trayectorias de violencia. Homicidios 2008-2014, (1 julio). https://www.nexos.com. $\mathrm{mx} / \mathrm{p}=28803$

Boris O (2015) The upsurge of oil theft and illegal bunkering in the Niger Delta region of Nigeria: is there a way out? Mediterr J Soc Sci 6. https://doi.org/10.5901/mjss.2015.v6n3s2p563

Brantingham PJ, Tita GE, Short MB, Reid SE (2012) The ecology of gang territorial boundaries. Criminology 50(3):851-885

Calderón G, Robles G, Díaz-Cayeros A, Magaloni B (2015) The beheading of criminal organizations and the dynamics of violence in Mexico. J Confl Resolut 59(8):1455-1485

Celis MDPF, Luján EP, Garca A . (2020). Las olvidadas. Mujeres desplazadas en Durango, las otras víctimas de la guerra contra las drogas. Sociológica México, (99)

CITpax Observatorio Internacional (2012) Actores Armados Ilegales y Sector Extractivo en Colombia. V Informe, DDR - Ley de Justicia y Paz

Collier P Hoeffler A (2004) Greed and grievance in civil war, Oxford Economic Papers, Volume 56, Issue 4, October 2004, Pages 563595, https://doi.org/10.1093/oep/gpf064, 595

Dell M (2015) Trafficking networks and the Mexican drug war. Am Econ Rev 105(6):1738-1779

Dube O, García-Ponce O, Thom K (2013a) From maize to haze: agricultural shocks and growth of the Mexican drug sector. In: CAF working paper, 2013/09. CAF, Caracas

Dube A, Dube O, Garcia-Ponce O. (2013b). Cross-border spillover: U.S. gun Laws and Violence in Mexico. Am Polit Sci Rev, 107(3), 397-417. Retrieved from http://www.jstor.org/stable/43654914

Dube O, García-Ponce O, Thom K (2016) From Maize to Haze: Agricultural Shocks and the Growth of the Mexican Drug Sector. J Eur Econ Assoc 14(5):1181-1224. https://doi.org/10.1111/jeea.12172

Dube O, Vargas JF (2013). Commodity Price Shocks and Civil Conflict: Evidence from Colombia, The Review of Economic Studies, Volume 80, Issue 4, October, 13841421, https://doi.org/10.1093/restud/ rdt009

Duran-Martinez A (2015) To kill and tell? State power, criminal competition, and drug violence. J Confl Resolut 59(8):13771402-13771402. https://doi.org/10.1177/0022002715587047

Escalante Gonzalbo F (2011a) Homicidios 2008-2009. La muerte tiene permiso. Nexos. Retrieved from: https://www.nexos.com.mx/?p=14089

Escalante Gonzalbo F (2011b) Respuesta a José Merino. Animal Politico. Retrieved from: https://www. animalpolitico.com/blog-invitado/respuesta-a-jose-merino/

Escamilla-Hamm P (2020) "The Guardia Nacional (National Guard): Why a New Militarized Police in Mexico.” Small Wars Journal. Retrieved from https://smallwarsjournal.com/jrnlnacional-national-guardwhy-new-militarized-police-mexico

Fearon J, Laitin D (2003) Ethnicity, Insurgency, and Civil War. Am Political Sci Rev 97(1):75-90. https://doi. org/10.1017/S0003055403000534

Fisher S (2020) “A Fractured System - Mexico’s Criminal Investigation Network.” InSight Crime. Retrieved from: https://insightcrime.org/news/analysis/a-fractured-system-mexico/

Flores MI, Atuesta L (2018). Mourning our dead: The impact of Mexicos war on drugs on citizens depressive symptoms. International Journal of Drug Policy, Volume 60, 6573

Ford A (2021)." Mexico City’s roaring trade in wildlife trafficking." Insight Crime. Retrived from https:// www.insightcrime.org/news/analysis/mexico-city-wildlife-trafficking/

Fuerte Celis M. del (2016) Geograf'ia de la violencia en M'exico. Un acercamiento a la reconfiguraci'on territorial de la violencia generada por el crimen organizado, Cuadernos de Trabajo del Monitor del Programa de Pol'itica de Drogas, CIDE-PPD, p. 1-42 
Garat G (2020) "Mxico: en el pas de los muertos nadie sabe quin muere.” La Diaria. Retrieved from https:// ladiaria.com.uy/lento/articulo/2020/6/mexico-en-el-pais-delos-muertos-nadie-sabe-quien-muere/

Guerra E (2016) Voces silenciadas. Las formas de morir de los periodistas en M'exico en el contexto del crimen organizado. Cuadernos de Trabajo del Monitor del Programa de Pol'ıtica de Drogas, CIDE Regin Centro

Guerrero E (2011) La ra'1z de la violencia. Nexos (1 junio)

Guerrero E (2019) “Tlahuelilpan, the Army and the National Guard.” El Financiero. Retrieved from: https:// www.elfinanciero.com.mx/opinion/eduardo-guerrero-gutierrez/tlahuelilpan-el-ejercito-y-la-guardianacional/

Heinle K et al (2015) Drug Violence in Mexico Data and Analysis Through 2014. Justice in Mexico Project. Department of Political Science International Relations. University of San Diego. p. 1-60

Ikelegbe A (2005) The economy of conflict in the oil rich Niger delta region of Nigeria. Nord J Afr Stud 14(2): 208234

Jones NP, Sullivan JP (2019) Huachicoleros: criminal cartels, fuel theft, and violence in Mexico. Journal of Strategic Security 12(4):1-24. https://doi.org/10.5038/19440472.12.4.1742

Kenny PD, Shrestha R, Aspinall E (2020) Commodity Booms, Conflict, and Organized Crime: Logics of Violence in Indonesia's Oil Palm Plantation Economy, Departmental Working Papers, The Australian National University, Arndt-Corden Department of Economics. https://EconPapers.repec.org/RePEc:pas: papers:2020-23

Lauritsen JL, White N (2014) "Seasonal Patterns in Criminal Victimization Trends." Washington DC: U.S. Department of Justice, Bureau of Justice Statistics. NCJ245959

Le Billon P (2001) The political ecology of war: Natural resources and armed conflicts. Political Geography 20:561-584. https://doi.org/10.1016/S0962-6298(01)00015-4

Malone D Berdal M (2000) Greed and Grievance: Economic Agendas in Civil Wars (Introduction) GREED AND GRIEVANCE: ECONOMIC AGENDAS IN CIVIL WARS, Mats Berdal and David M. Malone eds., Boulder, Col: Lynne Rienner Publishers, 2000, Available at SSRN: https://ssrn.com/abstract=1308996

Merino J (2011). Los operativos conjuntos y la tasa de homicidios: Una medición. Nexos (1 junio). https:// www.nexos.com.mx/?p=14319

Molzahn C, Ríos V, Shirk D. (2012). Drug violence in Mexico: data and analysis through 2011 trans-border institute Joan B. Kroc School of Peace Studies University of San Diego Ros

Open Society (2016). Atrocidades Innegables. Confrontando crímenes de lesa humanidad en México. Mexico: Open Society Foundations, 1-230

Osorio J (2015) The contagion of drug violence: spatiotemporal dynamics of the Mexican war on drugs. J Confl Resolut 59(8):14031432

Paternoster R, Brame R, Mazerolle P, Piquero A (1998) Using the correct statistical test for the equality of regression coefficients. Criminology 36(4):859-866

Pereda V (2018) Burning bridges: why don’t organized crime groups pull back from violent conflicts? Global Crime 19(1):6384

Pérez Correa C (2019) "El punto sin retorno en México: militarización o régimen civil." The New York Times. Retrieved from https:/www.nytimes.com/es/2019/02/05/espanol/opinionacional-senado.html

Phillips MD (2016) Time series applications to intelligence analysis: a case study of homicides in Mexico. Intell Natl Secur 31(5):729-745. https://doi.org/10.1080/02684527.2015.1093292

Poiré A, Martínez MT (2011) La caída de los capos no multiplica la violencia el caso de Nacho Coronel. Nexos January 5:2011

Ríos V (2015) How government coordination controlled organized crime: the case of Mexicos cocaine markets. J Confl Resolut 59:1433-1454

Rosas G (2012) “Los números de la guerra: ¿error de cálculo político o estadístico?” Blog de la redacción de Nexos. Retrieved from: https://redaccion.nexos.com.mx/los-numeros-de-la-guerra-\%C2\%BFerror-decalculo-politico-o-estadistico-respuesta-a-jose-merino/

Thoumi F (2010) The relationship between illegal drugs and violence: is there a cause and effect? Portal, Issue 5

Tucker D (2020)." Mexico's new National Guard is breaking its vow to respect human rights." Amnesty International. Retrieved from https://www.amnesty.org/en/latest/news/202national-guard-breaking-vowrespect-human-rights/

Trejo G, Ley S (2018) Why did drug cartels go to war in Mexico? Subnational party alternation, the breakdown of criminal protection, and the onset of large-scale violence. Comp Political Stud 51(7): 900-937. https://doi.org/10.1177/0010414017720703

Valdés Castellanos G (2013) Historia del narcotráfico en México. Aguilar, México

Espinosa V, Rubin DB (2015) Did the military interventions in the Mexican drug war increase violence? Am Stat 69(1):17-27. https://doi.org/10.1080/00031305.2014.965796 
Villarreal A (2002) Political competition and violence in Mexico: hierarchical social control in local patronage structures. Am Sociol Rev 67:47798

Wagner L (2016) “Organized Crime and Illegally Mined Gold in Latin America”. The Global Initiative against Transnational Organized Crime. Retrieved from: https:/globalinitiative.net/wp-content/uploads/2016/03/ Organized-Crime-and-Illegally-Mined-Gold-in-Latin-America.pdf

Yashar, Deborah. (2018). Homicidal ecologies: illicit economies and complicit states in Latin America

Publisher's note Springer Nature remains neutral with regard to jurisdictional claims in published maps and institutional affiliations. 